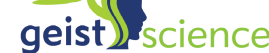

\section{Journal of Management Sciences \\ Earnings Manipulation and the Cost of Capital: Empirical Investigation of Non-Financial Listed Firms of Pakistan}

\section{Affiliation:}

Muhammad Ilyas

Lecturer, IBL, Abdul Wali Khan University Mardan.

Email: milyas_85@awkum.edu.pk

\section{Ihtesham Khan}

Assistant Professor at IBL, Abdul Wali Khan University Mardan.

Email: ihtishamkhan@awkum.edu.pk

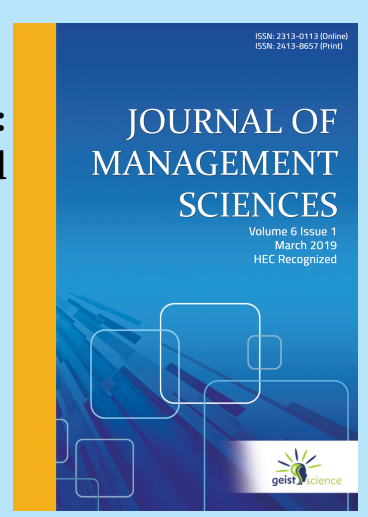

Saima Urooge

Assistant Professor at Department of Economics, Islamia College University

Peshawar.

\section{Manuscript Information}

Submission Date: April 27, 2019

Acceptance Date: June 14, 2019

\section{Citation in APA Style:}

Ilyas, M., Khan, I., \& Urooge, S. (2019). Earnings Manipulation and the Cost of Capital: Empirical Investigation of Non-Financial Listed Firms of Pakistan, Journal of Management Sciences, 6(1), 96-104.

DOI: https://doi.org/10.20547/jms.2014.1906107 


\title{
Earnings Manipulation and the Cost of Capital: Empirical Investigation of Non-Financial Listed Firms of Pakistan
}

\author{
Muhammad Ilyas * $\quad$ Ihtesham Khan ${ }^{\dagger} \quad$ Saima Urooge ${ }^{\ddagger}$
}

\begin{abstract}
Management either for their informative or opportunistic purposes mask the true financial information of firms which is known as earnings manipulation practices. However, in turn such practices lead to a higher cost of capital. Therefore, in this study examined the effect of earnings manipulation on cost of capital in 144 listed sample firms of Pakistan Stock Exchange for the period of 2006-2016. Used panel data approaches for analysis and the diagnostic tests procedures of panel models selection suggests that fixed effect model is the suitable model. The result reports that firms that indulge in the activities of earnings manipulation their cost of capital are high because the manipulated information reduces the confidence of investors on fundamentals information of firms and ultimately they demand high rate of return. Moreover, control variables such as size, capital structure, firm performance, market risk and capital expenditure significantly affect the cost of capital and the results are consistent with the theoretical and empirical justifications. Hence, the study recommended for the policymakers to develop regulated policies to control the earnings manipulation.
\end{abstract}

Keywords: Earnings management, cost of capital, discretionary revenue model.

\section{Introduction}

In the recent past a number of businesses are failed such as Enron, Parmalat and WorldCom. The failure of these businesses reflect the accounting scandals. Hence, regulations like Sarbanes-Oxley act are initiated (Stubben, 2010). Moreover, reports that such businesses failure is the outcome of earnings manipulations (earnings management) (Khalil, 2010). The practices of earnings manipulations are presented in literature by various terminology such as window dressing and big bath etc (Stolowy \& Breton, 2004). Moreover, EM is defined as:

"Managers use judgment in financial reporting and in structuring transactions to alter financial reports to either mislead some stakeholders about the underlying economic performance of the company, or to influence contractual outcomes that depend on reported accounting numbers" (Healy $\mathcal{E}$ Wahlen, 1999)

Further, McNichols (2000) argues that in academic accounting literature and in some popular press EM received more attention. In the similar vein, (Beneish, 1999) reports that:

\footnotetext{
*Lecturer, IBL, Abdul Wali Khan University Mardan. Email: milyas_85@awkum.edu.pk

$\dagger$ Assistant Professor at IBL, Abdul Wali Khan University Mardan. Email: ihtishamkhan@awkum.edu.pk

¥Assistant Professor at Department of Economics, Islamia College University Peshawar. Email: saimaurooge@icp.edu.pk
} 
"The extent to which earnings are manipulated has long been of interest to analysts, regulators, researchers, and other investment professionals."

For this purpose, a number of models are developed and tested by researchers to detect earnings management (EM) practices in which management is indulge. However, all such models have their own limitations such as (Kasznik, 1999; Jones, 1991), Modified Jones modes (Dechow, Hutton, Kim, \& Sloan, 2011) and Performance matched model (Kothari, Leone, \& Wasley, 2005). Moreover, reported that all these models are accruals based models. Bernard and Skinner (1996) depict that accruals based models generate noisy and biased results, therefore these models are criticized in empirical research. To solve the issues related with EM model Stubben developed his model. His model is based on discretionary revenue instead of accruals. He reports that his model detects the manipulation practices of management while the accruals based models do not. Further, he shows that his model is more powerful, less biased and better specified as compared to accruals based models because discretionary revenue model detect manipulation activities. Additionally, reports that his model combined expenses and revenue manipulation. Furthermore, the literature reveals that the manipulation practices shattered the confidence of investors on the firm fundamentals information and ultimately, these practices increase the cost of capital $(\mathrm{CoC})$. On the other hand, the management continuously trying to reduce the level of $\mathrm{CoC}$ to the lowest possible level. Further show that the lowest possible $\mathrm{CoC}$ increases the value of firm. The literature in this context are largely missing in Pakistan. Therefore, this study investigates to use the discretionary model to study the effect of EM practices of management on the CoC of firms listed on Pakistan stock exchange (PSX) to empirically reveal the platform for policymakers to concentrate to avoid EM practices of Pakistani listed firms. Therefore, selected sample of 144 listed firms and used approaches of panel data because the data used in this research is panel in nature. Through the models selection procedures of panel data techniques conclude that fixed effect is the suitable model of analysis.

\section{Literature Review}

Seminal work on earning manipulation has primarily focused on the managerial level incentives to manage earnings in a single firm setting. For instance, Dye (1988); Evans and Sridhar (1996); Demski (1998) presented models in which it was postulated that manager, by assumption is unable to communicate relevant private information to shareholders. In the similar context, Bar-Gill and Bebchuk (2002) also developed a framework and asserted that in order to obtain better terms while raising investments for new projects, firms misreport their performance.

Moreover, Povel, Singh, and Winton (2007) studied earning manipulation in a setting of multiple firms that seek investment from outside. Their results showed that a firm's decision of earning manipulation depends on the investor's belief on the state of the economy. They also reported that more likely, firms manipulate their financial reports in relatively good economic conditions.

Strobl (2013) also assessed the role of earning management in influencing a firm's cost 
of capital. By using agency model with multiple firms with intercorrelated cash flows, they showed that the earning manipulation varies with the changes in the business cycle. They also found that during expansionary period of the economy, managers of firms are more inclined towards earning manipulation. This dependence of earning manipulation on the economic condition, earning manipulation affects firm's cost of capital.

Another study was conducted by Bisogno and De Luca (2015). They examined relationship between financial distress and earnings management practices for the nonpublicly listed small and medium enterprises in Italy. They found that private SMEs in Italy which are facing bankruptcy, manipulate their earnings so as to portray better financial performance. They contended that earning manipulation generally takes place by inflating revenues and help a firm to maintain its bank financing and securing investments from outside.

Kim and Sohn (2013) also investigated if a firm's cost of capital is affected by the firm's real activities management. They used US firms as their study sample. They found that cost of capital positively affects the earning management. The overall results of their study suggest that good earning management activities spur the quality of information, which is further used by investors. Due to the quality information, investors demand higher risk premium. On the other hand, Nikoomaram, Arabahmadi, and Arabahmadi (2016) analyzed the effects of capital structure on earnings management. They have used 119 non-financial firms listed in Tehran stock exchange during the period 2000 to 2008. In this research, they have compared two different models, such as Jones Model and Modified Jones Model. Results suggest that debt ratio has a positive impact on discretionary accruals. Whereas, return on assets has a negative impact on debt ratio and equity has a positive impact on debt ratio.

\section{Methodology}

The main objective of the current paper is to empirically investigates the effects of earnings manipulation on the cost of capital of listed firms of Pakistan. To achieve the objective, the data of 144 non-financial listed firms were obtained from the period of 2006 to 2016. The data of all the variables were taken from the company's annual reports. Due to the unavailability of annual reports of several non-financial firms of Pakistan, only 144 companies have been used in the panel.

In accordance with the previous studies, the following framework is used to investigate the studied relationship. The parametric form of model is given below;

$$
C o C_{i t}=\beta_{0}+\beta_{1} E M_{i t}+\beta_{1} \text { Size }_{i t}+\beta_{1} C S_{i t}+\beta_{1} \operatorname{Perf}_{i t}+\beta_{1} \text { Beta }_{i t}+\beta_{1} C E_{i t}+\epsilon_{i t}
$$

Where, $C o C$ is the cost of capital, $E M$ is earnings manipulations, $C S$ is capital structure, $\operatorname{Per} f$ is the firm's performance, Beta denotes as the level of risk and $C E$ is capital expenditures of firms. The subscripts $i$ is the number of listed non-financial firms, whereas $t$ denotes the time period starting from 2006 to 2016. 


\section{Variables Descriptions}

The interest variable of the study is cost of capital and earnings manipulations. Cost of capital is defined as the weighted average cost of different capitals. In order to measure the cost of capital, we used a formula of weighted average cost of capital (WACC) suggested by Pierru (2009), which comprises of both the cost of equity and debt. The formula of WACC is as under;

$$
W A C C=W_{\text {eight }} D R a t e D\left(1-\text { Tax }_{c}\right)+W_{\text {eight }} \text { ERateE }
$$

Here, the WACC is the weighted average cost of capital, Weight $\mathrm{E}$ is the equity ratio in firm's capital structure, Taxc is the corporate tax rate, RateD is the cost of debt in the firm's outstanding debt, and RateE is the cost of equity.

In addition to the above, the other interest variable earnings manipulation is measured by the discretionary revenue model suggested by Stubben (2010). The discretionary accrual model is given below;

$$
\begin{aligned}
& \Delta A C R_{i t}+\beta_{0}+\beta_{1} \Delta S_{i t}+\beta_{2} \Delta S_{i t}\left(S_{i z e}\right)+\beta_{3} \Delta S_{i t}\left(A g e_{i t}\right)+\beta_{4} \Delta S_{i t}\left(A g e S q_{i t}\right) \\
& +\beta_{5} \Delta S_{i t}\left(G R R P_{i t}\right)+\beta_{6} \Delta S_{i t}\left(G R R N_{i t}\right)+\beta_{7} \Delta S_{i t}\left(G R M_{i t}\right)+\beta_{8} \Delta S_{i t}\left(G R M S q_{i t}\right)+\epsilon_{i t}
\end{aligned}
$$

Where, $\triangle A C R_{i t}$ is the change in account receivables, $\Delta S_{i t}$ is the change in sales, $S i z e_{i t}$ and $A g e_{i t}$ are the size and age of firms, $A g e S q_{i t}$ is the square of age of the firms, $G R R N_{i t}$ is the adjusted growth revenue of the firms, $G R M_{i t}$ is the adjusted growth of gross profit margin and $G R M S q_{i t}$ is the square of the adjusted growth of gross profit margin of the firm's.

In addition of the main variables, we have also used some control variables. Firm's size is used as a control variable to control the differences of earnings between the small and large firms. According to the past literature, total assets can be used as a proxy for measuring firm's size (Barghathi, 2014; Llukani, 2013; Xiaoqi, 2013). As stated by Pincus and Rajgopal (2002), large firm size predicts more earnings because of the more pressure stakeholders observe. Moreover, performance indicator is also used as a control variable, which represents how efficiently company's utilize their resources. Firms 'performance is measured by return on assets suggested by Almasarwah (2015); Barghathi (2014)'. Capital structure is used as control variable to capture the level of debt of the firms. It is measured by the ratio of total debt to total assets. Additionally, capital expenditure can also affect the level of cost of capital (Conyon \& He, 2011). It further stated that capital expenditure needs more monitoring mechanism in order to protect shareholder's wealth. 


\section{Results and Discussions}

$\begin{aligned} & \text { Table } 1 \\
& \text { Descriptive }\end{aligned}$ Statistics
\begin{tabular}{lcccccc} 
Variables & Mean & Median & St. Dev & Minimum & Maximum & Skewness \\
\hline EM & 0.01 & 0.09 & 1.00 & -2.35 & 2.44 & -0.33 \\
CoC & 1.56 & 1.11 & 3.12 & -5.03 & 9.74 & 0.39 \\
Size & 6.84 & 6.78 & 0.62 & 5.33 & 8.39 & 0.25 \\
CS & 0.55 & 0.55 & 0.22 & 0.00 & 0.99 & 0.07 \\
Perf & 0.06 & 0.05 & 0.11 & -0.53 & 0.29 & -0.23 \\
Beta & 0.74 & 0.74 & 0.61 & -0.97 & 1.99 & -0.12 \\
CapExp & 0.70 & 0.71 & 0.33 & 0.00 & 1.47 & 0.16 \\
\hline
\end{tabular}

Table 1 reports the descriptive statistics, on average the earnings manipulation practices of firms are low and it reveals that Pakistani listed firms use same standard of financial reporting. Moreover, reported that listed firms on average have high value of CoC. Further, reports that the sample listed firms on average depend on debt financing and it shows the confidence of creditors on the firm's performance. In the similar vein, find that the variation in the size of firms used in this study is small as illustrated by the minimum and maximum values. CE of the firms is high and it is due to the favorable environment for the expansion of business. ROA value on average is $6 \%$, this reports that the overall performance of these firms are good. In addition, the OCF on average is $8 \%$, which reveals that firms generate high level of cash flows from operating activities. Finally, conclude that sensitivity of the sample firms is low as compared to the level of market risk. However, table 1 shows that skewness of the variables presents that they are normally distributed.

\begin{tabular}{|c|c|c|c|c|c|c|c|}
\hline & $\mathrm{CoC}$ & EM & Beta & $\mathrm{CS}$ & Perf & Size & CE \\
\hline \multicolumn{8}{|l|}{$\mathrm{CoC}$} \\
\hline EM & 0.03 & & & & & & \\
\hline Beta & 0.86 & 0.02 & & & & & \\
\hline CS & -0.13 & 0.04 & 0.17 & & & & \\
\hline Perf & -0.05 & -0.06 & -0.18 & -0.48 & & & \\
\hline Size & -0.33 & -0.01 & -0.28 & 0.03 & 0.04 & & \\
\hline $\mathrm{CE}$ & -0.06 & -0.13 & 0.05 & 0.26 & 0.21 & 0.21 & \\
\hline
\end{tabular}

Table 2 presents that CoC is positively related with EM, Beta and CS of the sample firms. on the basis of this association demonstrated that if management indulge in earnings manipulation practices then the confidence of investors is reducing because such type of actions of management increase the level of risk of then. Therefore, they demand extra return in their investment to compensate high risk as compared to firms that cannot manipulate earnings. Moreover, reveal that the high beta pushes the level of CoC upward because high beta shows more risk of the firm, therefore investors demand high return on their investment. However, shows that performance of firm, size and capital expenditure negatively affect the CoC of listed firms on PSX. On the basis of association of CoC with these variables conclude that if firm perform well, large size firm and firms make more 
capital expenditures then their level of $\mathrm{CoC}$ is low because investors confidence on such firms are high and they cannot demand high returns as compared to market.

Table 3 reports the main findings of the study that EM significantly and positively affect the CoC of firms listed on PSX. Earnings manipulation of firms effect the investment decisions of investors. This shows that of management indulge in earnings manipulation then the agency cost become high, moreover, the manipulation conveys signal to the market about firm performance. Therefore, the findings are supported through agency and signaling theory of cost of capital. Moreover, conclude that capital structure and Beta significantly and positively affect the CoC of Pakistani listed firms.

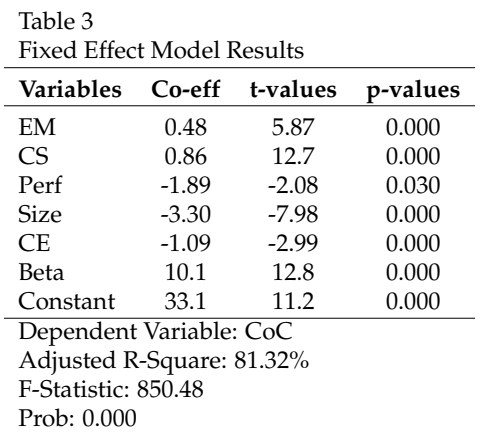

The findings of this study are consistent with the results of Strobl (2013) that risk and cost of capital are positively associated because investors of high risk firms demand more return on their investment. This reveals that in the capital structure the level of debts when increases than the chances of bankruptcy of firms become high. Thus, investors demand a high rate of return on their investment and ultimately the $\mathrm{CoC}$ is increasing. The effect of capital structure on CoC is consistent with Balvers (2009); Salteh, Valipour, and Zarenji (2012). However, CE, ROA and size of the firms negatively and significantly affects the CoC of listed firms on PSX. From the results find that if level of CE increases then it shows that firms become avail opportunism for expansion and ultimately generate high returns. Hence, the $\mathrm{CoC}$ of firms are reduces and convey positive signal into capital market. These findings supported the findings of McConnell (1985); Pfeffer (1972). Moreover, the firm performance and size significant and negative affect on $\mathrm{CoC}$ of listed firms shows that the cost of capital becomes low. The significant and negative affect of firm performance on CoC have matching with the findings of Harris and Raviv (1991) that more profit generating firms have less chances of bankruptcy, therefore the level of $\mathrm{CoC}$ is decline. In addition, find that large size firms get financing at lower possible costs.

Finally, the results explained that the model is valid because p-value of F-statistic is highly significant and the F-statistic is also high. Moreover, the model explanatory power of the model is $81.32 \%$. it shows that the explanatory variables explained the dependent variable is high. In addition to this, the result of Hausman test reveals that the p-value is less than the significance level of 0.05 , therefore fixed effect model approach is the appropriate technique for the analysis of this study. On the basis of this test report the fixed effect model results in table 3 of the study. 


\section{Conclusion}

Earnings manipulation is dilemma since the failure of largest businesses around the globe. Earnings manipulation generated a number of questions about the governance system, legal system and capital markets of the world. Such behavior of management also negatively affects the $\mathrm{CoC}$ of firms because it reduces the confidence of investors, thus investors demand a high return on their investments to compensate uncertainty. In this study investigated the effect of EM on $\mathrm{CoC}$ by using the discretionary revenue model of Stubben (2010) in a sample of 144 listed firms of PSX during 2006-2016. For analyses used the panel data techniques because the data is secondary and panel in nature. Results conclude that firms whose management indulge in earnings manipulation their $\mathrm{CoC}$ is high as compared to firms whose management cannot involve in earnings manipulation practices because the EM positively and significantly affect the CoC. Moreover, reports that capital structure, firm performance, size of the firm, capital expenditure and Beta significantly affect CoC of firms listed on PSX. 


\section{References}

Almasarwah, A. K. (2015). Earnings management and its relationship with corporate governance mechanisms in Jordanian industrial firms (Unpublished doctoral dissertation). (c) Adel Almasarwah.

Balvers, S. A. (2009). Earnings management and the cost of capital. (Master thesis). Erasmus University Rotterdam, Rotterdam, Netherlands.

Barghathi, Y. (2014). Perceptions of earnings management in Libyan commercial banks: An accountability perspective (Unpublished doctoral dissertation). University of Dundee.

Bar-Gill, O., \& Bebchuk, L. A. (2002). Misreporting corporate performance. Harvard Law and Economics Discussion Paper No. 400.

Beneish, M. D. (1999). The detection of earnings manipulation. Financial Analysts Journal, 55(5), 24-36.

Bernard, V. L., \& Skinner, D. J. (1996). What motivates managers' choice of discretionary accruals? Journal of Accounting and Economics, 22(1-3), 313-325.

Bisogno, M., \& De Luca, R. (2015). Financial distress and earnings manipulation: Evidence from Italian SMEs. Journal of Accounting and Finance.

Conyon, M. J., \& He, L. (2011). Executive compensation and corporate governance in China. (ICS 2011-003). Retrieved from CornellUniversity , ILRSchool, InstituteforCompensationStudiessite.http:// digitalcommons.ilr.cornell.edu/ics/6

Dechow, P. M., Hutton, A. P., Kim, J. H., \& Sloan, R. G. (2011). Detecting earnings management: A new approach. The Accounting Review, 70(2), 193-225.

Demski, J. (1998). Performance smoothing incentives (Tech. Rep.). Working paper, University of Florida.

Dye, R. A. (1988). Earnings management in an overlapping generations model. Journal of Accounting research, 195-235.

Evans, J. H., \& Sridhar, S. S. (1996). Multiple control systems, accrual accounting, and earnings management. Journal of Accounting Research, 34(1), 45-65.

Harris, M., \& Raviv, A. (1991). The theory of capital structure. The Journal of Finance, 46(1), 297-335.

Healy, P. M., \& Wahlen, J. M. (1999). A review of the earnings management literature and its implications for standard setting. Accounting Horizons, 13(4), 365-383.

Jones, J. J. (1991). Earnings management during import relief investigations. Journal of Accounting Research, 29(2), 193-228.

Kasznik, R. (1999). On the association between voluntary disclosure and earnings management. Journal of Accounting Research, 37(1), 57-81.

Khalil, M. M. M. (2010). Earnings management, agency costs and corporate governance: Evidence from Egypt (Unpublished doctoral dissertation). University of Hull, United Kingdom.

Kim, J.-B., \& Sohn, B. C. (2013). Real earnings management and cost of capital. Journal of Accounting and Public Policy, 32(6), 518-543.

Kothari, S., Leone, A. J., \& Wasley, C. E. (2005). Performance matched discretionary accrual measures. Journal of Accounting and Economics, 39(1), 163-197. 
Llukani, T. (2013). Earnings management and firm size: An empirical analyze in Albanian market. European Scientific Journal, 9(16), 135-143.

McConnell, J. (1985). Corporate capital expenditure decisions and the market value of the firm. Journal of Financial Economics, 14(3), 399-422.

McNichols, M. F. (2000). Research design issues in earnings management studies. Journal of Accounting and Public Policy, 19(4-5), 313-345.

Nikoomaram, H., Arabahmadi, F., \& Arabahmadi, A. (2016). The relationship between earning management and capital structure. International Journal, 1(1), 51-56.

Pfeffer, J. (1972). Size and composition of corporate boards of directors: The organization and its environment. Administrative Science Quarterly, 17(2), 218-228.

Pierru, A. (2009). The weighted average cost of capital is not quite right: A comment. The Quarterly Review of Economics and Finance, 49(3), 1219-1223.

Pincus, M., \& Rajgopal, S. (2002). The interaction between accrual management and hedging: Evidence from oil and gas firms. The Accounting Review, 77(1), 127-160.

Povel, P., Singh, R., \& Winton, A. (2007). Booms, busts, and fraud. The Review of Financial Studies, 20(4), 1219-1254.

Salteh, H. M., Valipour, H., \& Zarenji, S. S. N. S. (2012). Investigating the relationship between earnings management and weighted average cost of capital (WACC). Business and Management Review, 1(12), 28-38.

Stolowy, H., \& Breton, G. (2004). Accounts manipulation: A literature review and proposed conceptual framework. Review of Accounting and Finance, 3(1), 5-92.

Strobl, G. (2013). Earnings manipulation and the cost of capital. Journal of Accounting Research, 51(2), 449-473.

Stubben, S. R. (2010). Discretionary revenues as a measure of earnings management. The Accounting Review, 85(2), 695-717.

Xiaoqi, S. (2013). Earnings management, tunnelling behaviour and corporate governance: The case in China. Durham University. UK. Available at Durham E-Theses Online: http://etheses.dur.ac.uk/9414/. 